\title{
THE UNITED KINGDOM PARLIAMENT AND THE BRITISH NORTH AMERICA ACTS
}

\begin{abstract}
GEOFFREY MARSHALL*
This is the text of a presentation to the Kershaw Committee in the United Kingdom in 1980, and deals with the existence of a convention in respect to amendment of the B.N.A. Act and with the options available to the United Kingdom Parliament in dealing with the Canadian Resolution.
\end{abstract}

\section{THE QUESTIONS}

The two questions to be discussed here are:

1) Is there an accepted constitutional practice or convention that governs the amendment of the British North America Acts by the United Kingdom Parliament; and if so, what is it?

2) If there is no clear constitutional rule or practice to be followed, what are the options of the United Kingdom Parliament in respect of the forthcoming request for legislation from the Senate and House of Commons of Canada?

The questions for consideration by the Select Committee on Foreign Affairs are essentially questions of constitutional practice, since no issue has been raised about the legal position of the United Kingdom Parliament in relation to amendment of the British North America Act. (There are theoretical questions about the efficacy of s.4 of the Statute of Westminster in restricting the extension of British legislation to Canada without the request and consent of Canada, and about the legal relevance of that requirement to amendments of the B.N.A. Act, ${ }^{1}$ but these are of no practical concern.)

The facts defining the legal and constitutional background are also not in issue and they are sufficiently set out in the memoranda submitted by the Foreign and Commonwealth Office and the background paper prepared by the Canadian Department of External Affairs.

The statements made by Canadian federal Ministers and by British Ministers and Parliamentary spokesmen about the convention and practice governing amendments to the B.N.A. Act are, on the other hand, not matters on which there is general agreement since they have been contested both in Canada and in Britain.

\section{IS THERE A CONVENTION?}

The view that has been accepted by the British government and repeatedly asserted by the federal authorities in Canada is set out at p.9 of the External Affairs Department memorandum, conclusion (e):

The British Parliament or Government may not look behind any federal request for amendment, including a request for patriation of the Canadian Constitution. Whatever role the Canadian provinces might play in constitutional amendments is a matter of no consequence as far as the U.K. Government and Parliament are concerned.

- Fellow of The Queen's College, Oxford.

1. See infra n. 7 . 
This view is an understandable one for the Canadian government to take and there is a very good reason for taking it. British Ministers have said in the past on a number of occasions in the House of Commons that there is a practice of automatic action at the request of the Canadian federal authorities. The present Prime Minister and Foreign Secretary have acted on that belief in the assurances that they have given to Canadian Ministers.

But it may be argued that this ministerial belief is one that was formed initially in the 1940's in relation to amendments not raising issues of the present kind. It was formed without any full consideration or debate and has simply hardened into an article of faith, repeated without question in Parliamentary statements since 1940 that are now quoted in its support. Naturally, therefore, it has provided the basis of the advice given to, and assurances given by, successive Ministers who have themselves, understandably enough, not devoted much independent thought to the British North America Act or to the nature of federal government. Some reflection of that may be seen in the references in 1943 to the impropriety of questioning the discretion of Canada's "national and absolutely sovereign Parliament". Canada's federal legislature is not, of course, in any sense "absolutely sovereign" since its powers are allotted to it and limited by the Canadian constitution. At least some of the subsequent ministerial warnings against the impropriety of Westminster questioning any federal proposal seem to overlook the distinction between questioning Canada's sovereignty as a state and questioning the limited legislative sovereignty of its federal Parliament. No one doubts that the federal government represents and speaks for Canada in its external relations and foreign policy. But in the matter of constitutional legislation there is a limitation placed on the plenitude of its authority to act, placed on it not by the United Kingdom but by the people and constitution of Canada.

The precedents for amending the B.N.A. Act do not amount to a binding convention that is relevant to the present problem. A convention is created by the acceptance of a principle that is illustrated in a series of relevant precedents. The series of British amending Acts illustrates only:

1) That objections by one or two provinces have not been allowed to stand in the way of amendments that have either not affected or only doubtfully affected the federal-provincial balance of legislative powers.

2) That requests for amendment of the B.N.A. Act by provinces without the support of the federal government and Parliament will not be received.

There is no series of precedents and no single precedent on which to found a convention for acting automatically upon a federal request for an amendment that clearly affects the federal-provincial balance of powers (let alone the whole basis of the constitution)and is opposed by a substantial number of provinces (let alone a majority of provinces). Nor has there been any previous occasion when a statute has been enacted on the request and consent of Canada when a majority of the provinces of Canada were attempting to establish their rights to object to it in the Canadian courts.

The series of ministerial statements in the British Parliament cannot therefore properly be regarded as providing a clear convention for action in the present case and the decision required must be based upon a consideration of principle. 


\section{CANADIAN OPINIONS AND THE 1965 WHITE PAPER}

It is perhaps worth noting that though there has not until 1980 been any real consideration in Britain of the problem of B.N.A. Act amendments, the issue has been extensively discussed in Canada, and the view now taken by the British and Canadian governments cannot be said to be unequivocally supported by Canadian authority.

The Department of External Affairs paper appears to go further than is warranted by stating that an agreed convention denied the provinces any role in either requesting amendment of the B.N.A. Act or in requesting that the United Kingdom Parliament refuse to pass an amendment. ${ }^{2}$ The White Paper tabled in the Canadian House of Commons in $1965,{ }^{3}$ which presents four established conventions (see Appendix, infra), covers the first point. While Principles (1) and (2) were uncontroversial, the third Principle states that a province cannot unilaterally secure an amendment. ${ }^{4}$ None of the four Principles, however, denies the right of a province to object to a federal proposal before the United Kingdom Parliament.

Principle (4) is quite significant, and states that:

The Canadian Parliament will not request an amendment directly affecting federal-provincial relationships without prior consultation and agreement with the provinces. [emphasis added]

It is of course arguable that the breach of that convention, if it occurs in Canada, has no relation to the question of the British Parliament's action when faced with a federal request for legislation perhaps on the ground that the correct application of constitutional conventions in Canada is no concern of the British Parliament. Some Canadian constitutional authorities, however, have supposed that since the British Parliament is, with Canada's consent, part of Canada's constitutional amendment mechanism, the two issues are connected. Professor Paul Gérin-Lajoie, author of the leading work on constitutional amendment, stated that the Westminster Parliament has an obligation to concern itself with the working of the constitutional amendment process as a whole. ("Sur réception d'une demande d'amendement, Londres doit donc s'assurer avant d'agir que cette demande est faite conformément aux règles constitutionelles du Canada. "') Britain, he suggested, should not act on a Canadian request unless it could be seen to represent "la collectivité canadienne". Professor W. R. Lederman of Queen's University, Ontario, has also written: "I do not think the present convention permits the British Government and British Parliament to override any provincial dissent [where amendments affect the distribution of powers]. In the face of any provincial dissent I think the present convention requires that the British Government and Parliament do nothing, simply regarding the

2. Dept. of External Affairs, memorandum to the Kershaw Committee, at p. 6, para. E.

3. The Amendment of the Constitution of Canada, A White Paper of the Government of Canada (Ottawa, 1965). See Appendix infra.

4. See also E. E. Forsey, "Provincial Requests for Amendments to the B.N.A. Act" (1966) 12 McGill L.J. 397.

5. Gérin-Lajoie, "Du Pouvoir d'Amendement Constitutionel au Canada" (1951) Can. Bar Rev. 1136 at 1156. See the same writer's Constitutional Amendment in Canada (1950). One who took a different view was Professor W. P. M. Kennedy, author of The Constitution of Canada (2nd ed. 1937). See especially his evidence to the Special Committee of the Canadian House of Commons on the British North America Act, given in 1935. And see Proceedings and Evidence and Report (Ottawa, 1935) at 70ff.. 
request from the Canadian Parliament in these circumstances as improper."6 That is the view implicitly now taken by a majority of Canada's provincial governments.

\section{THE STATUTE OF WESTMINSTER AND BRITAIN'S POSITION}

It is perhaps necessary to recall that the Statute of Westminster is also part of Canada's constitutional structure. Britain's role in Canada's amendment process is not a mere anachronistic survival of Imperial legislative authority, but one exercised at the instance of Canada and given to it of set purpose in 1931 jointly by both provincial and federal authorities. One part of the liberating mechanism employed in the Statute of Westminster (s.2) takes the form of empowering the Parliaments of the Dominions to repeal any existing or future British Act of Parliament in its application to the Dominions. That power would, if unqualified, have given the federal Parliaments in both Canada and Australia an apparently unrestricted authority to repeal or amend their own constitution Acts (the B.N.A. Acts and the Commonwealth of Australia Constitution Act, 1900) thus overthrowing the federal division of powers. Neither the provincial nor the federal authorities in either country wished that to be possible. Both requested the insertion of provisions in the Statute of Westminster to remove the Constitution Acts themselves from the scope of the newly conferred power to repeal British statutes and to legislate repugnantly to the law of England. These are found in sections 7,8 and 9. At the same time, section 4 of the Statute retained the mechanism by which a British enactment might extend as part of Dominion law at the request and consent of the Dominion. ${ }^{\text {? }}$

The mechanism for forwarding Canadian requests for British legislation by resolution of the federal Parliament was of course familiar in 1931, since it had then been established for sixty years. ${ }^{8}$ No one at that time would have supposed that it could be used to evade the protection that had been inserted in section 7 of the Statute of Westminster to prevent unilateral alteration of the existing constitutional balance and the rights of the provinces by the federal Parliament under section 2. Thus the British Parliament was given a role in its amending process by Canada; but Canada would have been wasting its time if it had intended the British Parliament unquestioningly to carry out the instructions of the federal Parliament in effecting amendments to the B.N.A. Act that the latter could not bring about in Canada on its own authority.

A parallel may be drawn with Australia. There, the Statute of Westminster itself provided that the request and consent of Australia for British

6. W. R. Lederman, "The Process of Constitutional Amendment for Canada" (1966) 12McGill L. J. 371 at 379 .

7. Though the enactment of amendments to the B.N.A. Act since 1931 has not been because of the requirement of s.4 of the Statute of Westminster (since by s.7 nothing in the Act including the request and consent provisions of $s .4-$ is to apply to the amendment of the B.N.A. Acts, 1867-1930). So for that purpose the position remained as it was, the request and consent of Canada being required by the convention existing before 1931 (mentioned in the Statute of Westminster preamble) and not by the legal requirement of the Statute itself. The recitals of Westminster B.N.A. Act amendments have not, in fact, consistently embodied the express recital of Canada's request and consent mentioned in s.4.

8. It dates from 1871 . 
legislation should be signified by the Parliament and government of the Commonwealth. Australia, of course, already had an indigenous amendment process involving a majority vote of both electors and states in a referendum. Similarly, Australia could hardly have intended the British legislation, through the federal Parliament and government, to act as a licence to the federal authorities to obtain a constitutional amendment at Westminster that they could not procure through the constitutional referendum mechanism in Australia. The only unilateral request that has come from Australia has been from the side of the Australian states. The British Committee of both Houses, ${ }^{9}$ established in 1935 to consider the request for secession legislation by Western Australia, declined to recommend British action, referring to the fundamental principle that Parliament should act only at the request of the Dominion "speaking with the voice which represents it as a whole". It could be argued that that principle is a general one, though plainly it is a principle that involves difficulty and the exercise of judgment in its application.

\section{THE BRITISH NORTH AMERICA ACT (NO. 2) 1949}

Some reinforcement of this conclusion may be derived from a consideration of the British North America Act of 1949 and its interpretation by the Canadian courts. The British amendment of 1949 gave to the federal Parliament the power to amend the Constitution of Canada except in matters falling within the classes of subjects reserved to the provinces and certain other matters guaranteed in the British North America Act. This was interpreted as a measure to enable the federal Parliament to make amendments to the constitution, insofar as they affected the federal government itself, without recourse to the British Parliament.

Subsequent to 1949 the Parliament of Canada enacted the British North America Acts 1952, 1965, No. 2 of 1974, 1975 and No. 2 of 1975. It was acknowledged that none of this legislation affected federal-provincial relationships since it all dealt in various ways with the constitution of the Canadian Senate and House of Commons. In 1979, the Supreme Court of Canada described these Acts as "measures which according to the practice existing before 1949 would have been referred to the British Parliament by way of a joint resolution of both Houses and without the consent of the provinces". ${ }^{10}$ By contrast, a proposal to abolish the Senate would, in the Court's opinion, affect federal-provincial relationships and would require United Kingdom action. By implication it would not have been, under the established practice, referred to the British Parliament without the consent of the provinces. The practice referred to, and set out in the opinion of the Court, is Principle Four of the 1965 White Paper as already noted: "the federal Parliament will not request an amendment directly affecting federal-provincial relationships without prior consultation and agreement with the provinces". ${ }^{11}$

9. H. L. 75, H. C. 88 (1935).

10. Reference by the Governor in Council concerning the legislative authority of the Parliament of Canada in relation to the Upper House [1980] 1 S.C.R. 54 at 65; (1979) 102 D.L.R. (3d) 1 at 8.

11. Supra n. 3 at 16. It adds that: "The nature and degree of provincial participation in the amending process, however, have not lent themselves to easy definition." 
A distinction may be seen, therefore, between British amending Acts before and after 1949. Before 1949 some British amendments to the B.N.A. Act did not affect federal-provincial relationships and did not for that reason fall within Principle Four of the 1965 White Paper. Since 1949 such amendments have not required British action since they can be enacted in Canada by the federal Parliament. All amendments that require British action now affect either reserved matters or federal-provincial relationships to which Principle Four relates. A change in the amendment process certainly falls within that principle.

\section{SUMMARY OF HISTORICAL BACKGROUND}

In reviewing the historical background, it may be concluded that the repeated statements in the United Kingdom House of Commons as to the existence of a convention of automatic action on all federal requests for amendment of the British North America Acts (on which both British and Canadian Ministers have relied in good faith) should not be accepted as correctly stating the role of the United Kingdom Parliament in Canada's amendment process. This conclusion does not rest simply upon Canadian practice, since the basis for both the conclusion and that practice itself is the Statute of Westminster and the constitutional arrangements embodied in it to safeguard Canada's federal structure. The Statute of Westminster is part of the law both of Canada and of the United Kingdom.

The United Kingdom Parliament is not obliged to act automatically on a request by the federal Parliament to amend the British North America Act on matters affecting the federal-provincial distribution of authority. It is entitled to have regard to the constitutional practice governing requests for United Kingdom action recognized in the 1965 White Paper on the Amendment of the Constitution of Canada and noted in the opinion of the Canadian Supreme Court in the Senate Case of 1979.

\section{THE PROPOSED AMENDMENT LEGISLATION AND THE "FEDERAL-PROVINCIAL BALANCE"}

The term "federal-provincial balance" or "federal-provincial distribution" of powers perhaps needs some clarification, since the argument that amendments to the B.N.A. Acts directly affecting it need provincial consent assumes that such amendments can be clearly identified. There has not always been agreement in Canada as to whether a particular proposal for amendment did or did not affect the distribution of authority. An example was the proposal for reorganizing the Senate that was referred to the Supreme Court in 1978.

During the present debate in Canada it has on some occasions been said that "patriating" the constitution might not in itself affect the relative balance of powers between the federal and provincial authorities but leave them unchanged. A similar suggestion has been made about constitutional legislation for a new Charter or Bill of Rights (perhaps on the ground that it would change and restrict all legislative powers - both federal and provincial - equally).

But the expression "affecting the federal-provincial balance" is only an approximate, and perhaps in some ways misleading, term. It does not as such occur in any of the relevant legislation. The appropriate question is whether a proposed amendment directly affects the matters which fall outside the 
legislative competence of the Parliament of Canada. The way in which the federal Parliament is inhibited from changing what might be loosely called the federal balance or structure of the constitution is by denying it authority to remove or diminish the rights assigned by s.92 of the B.N.A. Act to the provinces, or the rights with respect to schools or language which were excepted from the power of constitutional amendment conferred on the federal Parliament by the B.N.A. (No. 2) Act of 1949. That the proposed Canada Act affects these matters must be presumed in its submission for United Kingdom enactment. If that were not so the legislation could obviously be passed in Canada under the power to amend the Constitution of Canada given by the 1949 B.N.A. Act.

In the matter of enacting a Charter of rights and freedoms it has been clearly recognized by the Canadian courts (and indeed it was assumed in all the discussions prior to 1960) that the present Bill of Rights enacted by the Parliament of Canada in that year does not apply to provincial legislation. It has also been acknowledged, at least since 1960, that a Bill of Rights for Canada as a whole could only be effectively promulgated by United Kingdom amendment of the B.N.A. Acts. Thus, at the present time the powers of the federal Parliament are limited (or at least conditioned) by a Bill of Rights and the powers of the provinces are not (though a minority have provincial charters). Plainly a new Bill of Rights applying to the provinces would operate to restrict all of the existing provincial legislative powers not now so restricted. If that is a reason why the federal Parliament could not itself enact such a Bill, the imposition of a Bill on the provinces by constitutional amendment could hardly be said not to be a measure affecting the allocation of authority in the federal structure.

The phrase "directly affecting federal-provincial relationships" has, it may be noted, occurred primarily in the context of argument about the constitutional practice and convention of the amendment process and was used in the 1965 White Paper to characterize amendments that, by such convention, required provincial consultation and agreement. If it were to be argued that an amendment to change the amendment process and to put an end to the role of the United Kingdom Parliament did not directly affect federalprovincial relationships, it would be hard to make sense of the series of Dominion and Federal-Provincial Conferences which have been held since the 1930 's. These conferences were designed to reach agreement on an amending formula - a matter which has for fifty years been thought to be central to the federal-provincial relationship. Likewise thought to be central has been the insistence of the provinces since the Imperial Conference of $1930^{12}$ on being parties to any change in the arrangements inserted on their behalf in the Statute of Westminster.

12. The Proceedings of the Conference recorded that the drafting of the sections relating to Canada in the proposed legislation was suspended to allow the views of the provinces to be obtained. (See Report of the Conference on Inter-Imperial Relations, Imperial Conference 1930, Cmd. 3717, esp. at 17-20.) A succinct account of the transactions leading up to the insertion of s.7 in the Statute of Westminster is given in Sir Kenneth Wheare's The Statute of Westminster and Dominion Status (3rd ed. 1947) at 182-191. 


\section{THE OPTIONS FOR UNITED KINGDOM ACTION}

The options for the United Kingdom Parliament seem to be as follows:

1) To pass the Canada Act and the Constitution Act as requested by the Senate and House of Commons of Canada without amendment, including the Charter of Rights and Freedoms and the repeal in relation to Canada of s.7(i) of the Statute of Westminster (together with a modification of s.4 removing the power of the United Kingdom to legislate for Canada). It is not entirely clear why, if the Constitution Act is passed so as to include a general amendment procedure, the repeal of s.7(i) is necessary.

2) To enact the Canada Act without Parts 1 and 2 of the Constitution Act (i.e. the Charter of Rights and Freedoms) so as to patriate the constitution but to do no more. This would not meet the present wishes of either the federal government or of the provinces but it might diminish the opposition to the passage of the Act and would give the provinces the opportunity to propose amendments to the amending process under the interim provisions set out in the legislation.

3) To take no action on the Canada Act but to enact a Canada Independence statute to give effect to a provision similar to that contained in s.2 of the proposed Canada Act - i.e. that from a date to be appointed no Act of the Parliament of the United Kingdom shall extend to Canada as part of its law - together with consequential provisions of the kind inserted in independence legislation such as that applied to Nigeria and subsequent Commonwealth independence enactments. This course has been advocated by some as one that would allow Canada to have a totally independent and "autochthonous" basis for its constitution, but this would be impracticable in Canada where the situation is not like that of Ireland in 1920 or Nigeria in 1960 or Rhodesia in 1965. Neither the federal nor provincial governments nor any other assembly would be able lawfully to set itself up as a constituent body and, as is noted at section C of the External Affairs Department paper, such a course would simply make a constitutional settlement legally impossible in Canada.

4) To defer action until the Supreme Court of Canada has decided appeals from the applications made by Manitoba, Quebec and Newfoundland to the provincial courts. With the minor exception of the legal proceedings in Newfoundland before the British North America (No. 1) Act, 1949 , there has been no precedent for mounting a substantial challenge to the actions of the federal authorities whilst a request for legislation was before the United Kingdom Parliament.

It is somewhat unclear precisely how the court decisions will bear on the decision to be made at Westminster. The applications are limited to determining whether the procedure followed in Canada is lawful and also whether it is contrary to Canadian constitutional practice. A decision that the procedure is unlawful would be relevant, but seems unlikely. A decision that the unilateral procedure for requesting British legislation is or is not contrary to Canadian constitutional practice (if the Canadian courts are willing to give an explicit ruling on the point) is not in itself a decision about the constitutional obligations of the United Kingdom Parliament to act upon the request. A decision of the Supreme Court of Canada would, however, provide a source of 
advice whose independent status could not be questioned, and which is different in character from any that is now available whilst the constitutional practice in Canada is an issue between the provincial and federal authorities.

5) An alternative to option (2) would be to attempt to secure federalprovincial agreement to what has been called "simple patriation" using the Fulton-Favreau formula, ${ }^{13}$ which secured almost universal agreement in 1964. It would simply require amendments affecting federal-provincial matters to have the assent of the federal Parliament and legislatures of all the provinces until agreement on a more flexible formula was reached by that process. A further meeting of federal and provincial prime ministers would seem a necessary prerequisite of any such course of action.

6) Indeed no course other than Option (1) could reasonably be taken without further British-Canadian consultation and some new diplomatic initiative by the United Kingdom Parliament. If it is the case that the present situation is unprecedented and not clearly governed by any agreed constitutional convention, the least damaging way forward might be seen in the convening of a new intergovernmental meeting or conference with British participation, if that is acceptable, to be directed primarily to the problem of ending the United Kingdom's role in Canada's constitutional processes. It seems regrettable if the time available for finding an agreed solution should be dictated by the exigencies of the 1981 United Kingdom Parliamentary timetable.

\section{THE OPTIONS FOR UNITED KINGDOM ACTION - ADDENDUM}

It may be useful to set out the range of legally possible courses of action. However, it is clear that they are not all options that are constitutionally available at the present time, since British legislation embodying them could not (under the Statute of Westminster conventions) be made to extend to Canada without Canada's request and consent. Furthermore, nobody has requested or consented to any partial enactment of the Canada Act, or to

13. The Fulton-Favreau formula was embodied in a draft statute in 1964 in the following terms:

Power to Amend the Constitution of Canada

(1) Subject to this Part, the Parliament of Canada may make ...

(2) No law made under the authority of this Part affecting any provision of this Act or section 51A of the British North America Act, 1867, or affecting any provision of the Constitution of Canada relating to

(a) the powers of the legislature of a province to make laws,

(b) the rights or privileges granted or secured by the Constitution of Canada to the legislature or the government of a province,

(c) the assets or property of a province, or

(d) the use of the English or French language,

shall come into force unless it is concurred in by the legislatures of all the provinces.

(3) 1. No law made under the authority of this Part affecting any provision of the Constitution of Canada that refers to one or more, but not all, of the provinces, shall come into force unless it is concurred in by the legislature of every province to which the provision refers.

2. Section 2 of this Act does not extend to any provision of the Constitution of Canada referred to in subsection 1 . of this section. 
British legislative abdication, or to simple patriation with a unanimity requirement.

This strengthens the case for believing that the British Parliament's proper aim should be to attempt to secure for itself the opportunity to be guided by Canadian constitutional practice as set out in the provincial advisory opinions and in the appellate decision of the Supreme Court of Canada.

The relation of these decisions to the matters to be placed before Parliament in the United Kingdom if a federal Parliamentary address is transmitted has now become much clearer. One of the questions in Manitoba's reference poses the question as to whether the consent of the provinces is required as a matter of constitutional practice before a request is made for British legislation which affects provincial powers. A further question asks whether consent is a prerequisite to the enactment of such legislation. The answers are no doubt advice and not legally binding on the Canadian authorities or on the United Kingdom Parliament, but if they are answered in the form posed they are obviously relevant to the questions posed at Westminster. Both simple rationality and the consideration that Westminster legislators should follow Canadian practice when acting as part of the Canadian amendment process, suggest that the answer to the second question turns upon the answer to the first - that is, that consent is a requirement for enactment if it is a requirement for a request for enactment. The convention, though it falls into two parts, is a single convention, and though it is (for the time being) both a British and a Canadian convention, its content should be determined in Canada.

If a clearly enunciated judicial statement of the convention were to support the federal government's position, the United Kingdom Parliament would have no constitutional alternative other than to act in accordance with it. If it did not support the government's position, the United Kingdom Parliament would have grounds for declining an unsupported request that could not be resented as improperly interventionalist. So to ask to know what Canadian practice is and to follow it seems the least improper and the most prudent of the options. 


\section{APPENDIX}

The four principles of the 1965 White Paper (as noted in the judgment of the Supreme Court of Canada): ${ }^{14}$

The first general principle that emerges in the foregoing resume is that although an enactment by the United Kingdom is necessary to amend the British North America Act, such action is taken only upon formal request from Canada. No Act of the United Kingdom Parliament affecting Canada is therefore passed unless it is requested and consented to by Canada. Conversely, every amendment requested by Canada in the past has been enacted.

The second general principle is that the sanction of Parliament is required for a request to the British Parliament for an amendment to the British North America Act. This principle was established early in the history of Canada's constitutional amendments, and has not been violated since 1895 . The procedure invariably is to seek amendments by a joint Address of the Canadian House of Commons and Senate to the Crown.

The third general principle is that no amendment to Canada's constitution will be made by the British Parliament merely upon the request of a Canadian province. A number of attempts to secure such amendments have been made, but none has been successful. The first such attempt was made as early as 1868 , by a province which was at that time dissatisfied with the terms of Confederation. This was followed by other attempts in 1869,1874 and 1887. The British Government refused in all cases to act on provincial government representations on the grounds that it should not intervene in the affairs of Canada except at the request of the federal government representing all of Canada.

The fourth general principle is that the Canadian Parliament will not request an amendment directly affecting federal-provincial relationships without prior consultation and agreement with the provinces. This principle did not emerge as early as others but since 1907, and particularly since 1930 , has gained increasing recognition and acceptance. The nature and the degree of provincial participation in the amending process, however, have not lent themselves to easy definition. 